\title{
A LIFE IN LETTERS: AN ANTHROPOLOGICAL REFLECTION ON THE CORRESPONDENCE OF SLOVENE MISSIONARY SR. CONRADINA RESNIK
}

\author{
Nataša ROGELJA CAF
}

COBISS 1.01

\section{ABSTRACT \\ A Life in Letters: An Anthropological Reflection on the Correspondence of Slovene Missionary sr. Conradina Resnik}

This article follows a circular path. Its starting point is the well-preserved family archive of more than a hundred letters written by Sr. Conradina to her family back home in Slovenia from her assigned mission in India. It then journeys through layers of historical context important for understanding the qualitative methodological approaches, reflecting on various aspects relevant to the analysis of the letters (material aspects, questions of comprehension, content issues, the ethnographic context, etc.). Finally, it reaches - or rather comes back to - the source, the missionary herself, writing letters from India to Slovenia from within the framework of different hierarchies, discourses and relationships.

KEY WORDS: heritage of Slovene women missionaries, life writing, letters, India, women migration

\section{IZVLEČEK}

\section{Življenje v pismih: Antropološka refleksija korespondence slovenske misijonarke,} sestre Konradine Resnik

Članek je zasnovan krožno. Pot začne s predstavitvijo v obsežnem družinskem arhivu zbranih pisem, ki jih je slovenska misijonarka sr. Konradina v prvi polovici prejšnjega stoletja pošiljala svoji družini v Slovenijo. V nadaljevanju predstavi nekatere zgodovinske okoliščine, pomembne za razumevanje kvalitativnih metodoloških pristopov, ponudi pa tudi vpogled $v$ različne plasti, pomembne pri analizi pisem (materialni aspekt, vprašanje obsega, vsebinska analiza, etnografski kontekst itd.). V zaključku se vrne na svoje izhodišče in osvetli akterko samo, slovensko misijonarko v Indiji, ki je v okviru različnih hierarhij, diskurzov in odnosov svojim domačim pošiljala pisma.

KLJUČNE BESEDE: dediščina slovenskih misijonark, življenjske zgodbe, pisma, Indija, ženske migracije

PhD in Social Anthropology, Research Fellow, Slovenian Migration Institute ZRC SAZU, Novi trg 2, SI-1000 Ljubljana; natasa.rogelja@zrc-sazu.si — The following article is part of the ARRS project "Slovene Women Missionaries in India: A Forgotten Chapter in Intercultural Relations" (2017-2020) led by Dr Ana Jelnikar and funded by the Slovenian Research Agency, and part of the ARRS programme "Heritage on the margins: New perspectives on heritage and identity within and beyond national" (P5-0408)) led by Dr Špela Ledinek Lozej. 


\section{INTRODUCTION}

You know, Ivo, the willow trees are all beautifully green and they've already reached over a meter in height. I spend time looking at them every day. And I tell them they shouldn't be homesick, that I'm from the same place as them. (16 August 1986)

On 18 January 2018 I received an e-mail from the grandnephew of Sr. Conradina, one of the early Slovene women missionaries in India, who first set foot on the subcontinent on 23 November 1933. He wrote:

... I just spoke with my uncle Marjan and briefly described your project to him. We are both very happy that you remembered our "aunt from India", as we used to call her, and we are willing to cooperate as best we can. We will also contact our aunt Ivanka, with whom I have some connections. As I said, I myself keep her letters addressed to my father and grandmother (her sister), and to my great-grandmother (her mother) and to other family members. I believe that my uncle and aunt also have some of her letters ...

A few days later, when I met Sr. Conradina's grandnephew, I was presented with a large black folder full of yellowing pieces of paper, letters carefully arranged in chronological order, from the first dated 14 November 1933 to the last written on 20 June 1997. The last one was in fact sent by St. Elizabeth's Hospital in Bombay (now Mumbai), informing the family about Conradina's passing on 24 May, and the first was written (in Croatian) by the Croatian sister Marija Benedikta Banek from Liege, informing the family about her departure to India. All the letters and postcards in between were written by Sr. Conradina herself to her family, with the exception of one or two. I remember being quite impressed seeing the concrete textual evidence of Sr. Conradina's existence in India. First of all, the black folder was there, ready to be handed over to me. This in itself was amazing, knowing that traces of women missionaries are not easy to come by, as women missionaries did not leave many written materials behind. So, hypothetically, I was looking at material that had the potential to reveal an undiscovered history. Secondly, it was tempting to understand these letters as a true account of (her) conditions. And this feeling persisted regardless of the fact that researchers are (or should be) by nature discerning, detached observers, well aware of the numerous layers under the manifest surface (Gerber 2006). When holding the thick leather folder in my hand, observing the thin yellowing paper scribbled over in different yet similar handwriting, from the strong youthful hand to a trembling line - it felt like holding a life in my hands. And that in itself produced a pattern of reverence, significant also for the critical observation of history.

Chatting with Andrej Kotnik, Sr. Conradina's grandnephew, over the course of the next two hours, I learned about the basic course of her life, eager to get as much data as possible before plunging into the letters. Andrej was a willing and generous informant, who was extremely interested in this part of his family history. Himself 
also a librarian, he had a passion for writing and researching, and was very articulate. He even prepared a short entry on Sr. Conradina for the local biographical lexicon ${ }^{1}$ several years ago. Let me cite it in full as a starting point:

Ivana Resnik left her home in Markovo very early. As a young woman, she was an assistant doctor in Zagreb, where she gained considerable medical knowledge through practical work. In Zagreb she met Jesuit missionaries who had gone to India, and became enthusiastic about the missions. Following the advice of the Jesuits, in 1928 she travelled to Belgium with four other women and joined the order of the Daughters of the Cross. There she took the name of Sr. Conradina. For the next two years she studied at the monastic house in Liège and later did one additional year of studies in London. She returned to Liège in 1931 and took her first vows. On 9 November 1933 she embarked on a journey from Belgium to India, where she first worked at the Catholic Girls' School in Bandra (Bombay), teaching religion in the morning and helping with embroidering missal cloths in the afternoon. Twenty years later, she was transferred to a larger hospital in Bombay, run by her community. She worked there initially as a nurse, and as the head of nursing then until retirement. She was the only Slovene among the hospital staff. She maintained close contacts with her homeland and family. She returned to Slovenia for the first time in 1965 and for the last time in 1988. She is buried in Bombay.

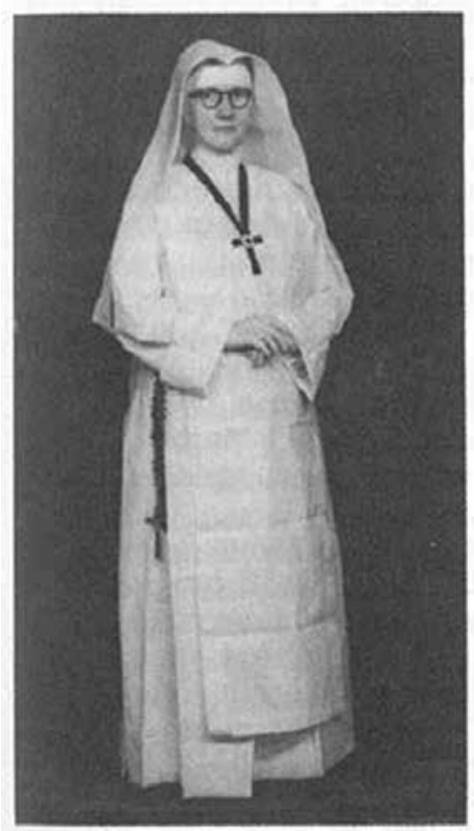

Kontadina Resnik 1962

Figure 1: Sr. Conradina Resnik (source: Kokalj 1989).

1 http://www.leksikon.si/Oseba/Osebald/48. 
In the course of our first conversation, one anecdote caught my immediate attention. Once, when Sr. Conradina was visiting her family, her sister Ana, seeing Conradina go out and about a lot, made a remark, suggesting ever so cautiously that her sister should be praying a little more. Upon which, according to Andrej, the missionary swung her head and hand in dismissal, replying: "C'mon Ana!" Over time this small incident turned into a family anecdote, evoked at family gatherings. Alongside this nugget of family history, after our conversation, I was left with a distinct feeling of Conradina's almost painful attachment to her family and homeland, as well as her love of elephants, numerous wooden sculptures of which she would often send or bring to her family. I wanted to make sense of these. In this quest we will journey through layers of historical context important for understanding the qualitative methodological approaches, reflecting on various layers relevant to the analysis of correspondence.

\section{A FEW HISTORICAL, METHODOLOGICAL AND EPISTEMOLOGICAL CONSIDERATIONS}

Before reflecting on the letters as a specific type of research material, let us briefly consider some of the historical contexts important for understanding the qualitative methodological approaches. Apart from the various labels attached to the so-called biographical approach and all heading in more or less the same post-modern direction - oral history, life history and life writing - what we are dealing here are also different scientific disciplines and their methodological, epistemological and theoretical developments over time.

Historian Alistair Thomson proposed four paradigmatic phases through which oral history evolved: the first is the post-WW II renaissance of memory as a source for history; the second phase relates to post-positivist approaches after 1970, the third dates to around 1980, and involves reflection on the role of the researcher, and the fourth is the digital revolution after 1990. Margaretta Jolly further reflected on these phases through three different fields related to researching "people's voices" (oral history, life history and life writing). These three categories are sometimes linked with specific disciplines (e.g. oral history with history) and/or with different theoretical traditions (e.g. life writings with postcolonial and postmodern theorists, recognising the heterogeneity of voices). They can also be seen in names of journals, conferences and institutes around which researchers with similar understandings and/or interests gathered. The boundaries between these fields, however, are not so clear as the descriptors themselves might suggest, and Jolly talks about them as family members, as siblings, cousins and aunts (2012: 47).

Although Thomson as a historian situated the beginning of contemporary oral history in the post-WW II period - in the period when (professional) historians recognised the validity of oral sources and when mobile tape-recorders began to be available - pinpointing the exact time of "the beginnings" is always negotiable. Jolly 
writes about the "documentary movement" (2012: 48) which predated this period, going back to the early $20^{\text {th }}$ century when British and American anthropologists, the Chicago School of Sociology and the British Mass Observation project (the latter recorded workers' everyday life in Britain through diaries ${ }^{2}$ ) had already drawn on personal testimonies and acknowledged the importance of this material for academic knowledge. From its methodological beginnings with Bronislav Malinowski, anthropology was also close to people's (hi)stories, using conversation and participant observation as the main methodological approach, while studying culture from the perspective of a member of that culture.

In 1926 the American anthropologist Paul Radin published a book entitled Crashing Thunder: The Autobiography of an American Indian, a pioneering attempt of professional biographical study or a life history approach, which opened the door to numerous (auto)biographical studies in the following decades. The Chicago School represents another important beginning of the life history approach, focusing on migrant narratives through biographies written by migrants, building sympathy for the voices from below, for those who were marginalised. This trend clearly echoed the values of many of the first wave of oral historians (e.g. Thompson 1988), as observed by Jolly (2012: 49). Experiments from literature, especially by the modernists and the "new biography" approaches (e.g. Virginia Woolf, for more see Saunders 2010) that were strongly influenced by psychoanalysis, should also have their place in the "beginnings section". As Jolly observed, all these experiments were part of the rebellion against nineteenth-century hagiography as well as psychological investigations fascinated with the nature of memory (ibid.).

According to Thompson, the approaches interested in subjectivity emerging in the second phase are also more similar to each other due to the fact that they have to enter into dialogue with various critics. These post-positivist approaches were articulated through various theoretical discussions, such as "symbolic interactionism" in sociology and "thick descriptions" in anthropology, leading towards numerous focused discussions on qualitative methodology (Denzin 1970). The third period coming after 1980 can be described as the most fruitful in terms of publications related to (auto)biography and qualitative methodology (Rogelja 2014) and is characterised by feminist political philosophy and preoccupations with the location and identity of both "biographer" and "biographee" (Jolly 2012: 50). In the late 1980s, various political testimonies (e.g. Holocaust testimonies) converged with the life story approaches and, from the context of trauma, challenged the limits of textual representations. Silences, unspoken words and gestures became equally important as the words spoken and heard in the qualitative approaches of the post-1980s.

The last period, as described by Thomson, is linked with the "digital revolution" where new information communication technologies transform the meaning of

2 In August 1939 the Mass Observation project invited members of the public to record and send in a day-to-day account of their lives in the form of a diary (see more Hall 2015). 
proximity and intimacy across borders and distance (Madianou, Miller 2012), enable new transnational practices and connections (Bofulin 2018) and re-address (old) methodological and epistemological questions in a new light. Forms of self-representation such as Facebook posts, YouTube and blog posts gave hope of a return to orality, but instead, new oral-literate and visual-verbal-virtual forms were born (Smith, Watson 2009 in Jolly 2012: 56). Some authors, such as Michael Frisch (2006), stressed how new digital tools can restore some of the original impulses in oral history, by allowing for the inclusive sharing of memory and the heterogeneity of self-referential practices. This links with the postmodern and postcolonial theorists (Smith, Watson 2001) who have criticized the previous terms (e.g. life history and oral history) in favour of more inclusive ones, namely life writings or life narratives (Lambert Hurley 2013; Karlekar 1993).

Where do letters sit in this debate? Recently, I became a Facebook friend with Sr. Conradina's grandnephew, who occasionally posts photos, stories and other materials from his family archive online. One such "online family project" was his Facebook album "Famous relatives", a collection of photos and texts that elicited numerous comments. This specific material (also featuring Sr. Conradina's letters), opened new dimensions of (family) engagement and understanding through digital tools. Sr. Conradina's words had a special resonance in the context of Facebook as they spoke directly to the group members, linking them in a dialogue over obedience. Sr. Conradina writes: "Do not forget, Tone, if you are honest and obedient, you will you'll never be sorry". One of Andrej's friends commented: "Is obedience really a good thing?"

Letters speak directly and they are a specific kind of "raw material" rather than "synthesized memory" (Lambert Hurley 2013), both similar and different to diaries and journals. They differ from diaries in their diverse motivation (family letters, formal administrative letters, love letters, correspondence between writers and scientists, etc.), in their broader range of authorship (including invisible, common people) and in the distance involved with letters (time and space gaps between writing and reading, and between writer and reader). As such, collecting letters presents challenges for the researcher, as letters become scattered over the globe and the researcher rarely has access to both sides of the correspondence. Although this "oneway conversation" gives an impression of isolation, letters do not exist, and are not created, in a vacuum. Letters are not only expressions of the writer but are also part of the mutual dialogue (specifically, between the writer and the reader), depending on the circumstances and individuals involved. The style and the content of the writing is further influenced by education, gender, the political circumstances in which the letters were written, social class, and we could go on. As historian Steven Stowe wrote, personal writing reveals how people both embraced and resisted the time and place in which they lived (2002). The historical richness of texts such as letters can be found precisely in the friction between the general forms available to writers and the individuals' use of them for their own purpose (ibid). 
Women missionaries' letters from the previous century can be put in the category of migrants' letters, the most widespread instrument of migrant communication during the $19^{\text {th }}$ and most of the $20^{\text {th }}$ centuries. Significantly more than newspapers and books, letters were a source of wisdom about life in a new location. They were the largest body of ordinary peoples' writings that researchers possess, and have become a recognised research resource in recent decades (Elliott, Gerber, Sinke 2006: 3; Kalc 2004: 153; Milharčič Hladnik 2009: 30-33). Following the fieldwork examples gathered for the project "Slovene Women Missionaries in India: A Forgotten Chapter in Intercultural Relations", letters can be considered as one of the main forms of self-expression for Slovene women missionaries and maybe one of the best sources to reflect on their agency (Jelnikar 2017). Similarly to what Lambert Hurley wrote about Muslim women writings (2013: 78), these missionary letters may be the key to reflect on questions such as: How do women's missionary writings differ from that of their missionary brothers in similar contexts? (see Motoh this volume) How do missionary women reflect on broader political and historical trends while also developing themes unique to their own experience? What was the core of the friction between the general forms available to Slovene women missionaries and the individuals' use of them for their own purpose? Let us first try and tackle the minutiae of missionary letters by trying to answer a simple question: How can letters be approached?

\section{LETTERS THROUGH LAYERS}

\section{The Materiality of Letters}

Steven Stowe wrote that personal texts from the past make an impression even before we see what they have to say (2002). The first layer of our analysis is thus the materiality of letters; assessing the various characteristics of letters as material objects and understanding information related to those characteristics. In other words, we have to take into account the information that exists beyond the epistolary narrative: the condition and texture of paper, the style of handwriting, the envelopes, the proportion of images, the way these "papers" were stored and by whom. All of this is information that can help with further analysis of the content. In the case of Sr. Conradina's letters, I first noticed the tidiness of the folder, the care that was invested in collecting and storing these letters, but also the family's willingness to share these fragile materials with researchers.

From the anthropological point of view, the present circumstances, the people who stored letters and talked about them, are very important for the analysis. Sr. Conradina's letters were collected by two of her nephews. I wondered - what if these letters had been written by some other family member, not by a missionary, would they have also been collected and stored in such a way? These letters, as suggested by Sr. Conradina's grandnephew in his Facebook album, are letters from 
a famous relative. This also suggests the hope invested in the folder, that perhaps someday this object might even enter the public domain, hence the readiness to share what might otherwise have been seen as strictly personal letters. There was indeed a measure of pride in having a missionary in the family. This fact might attest to a more general phenomenon, following Ingie Hovland's article on the Norwegian Mission Society (NMS), who noted that the image of the missionary as hero has deep roots (2009: 138). In the case of Sr. Conradina, this general positive image of a missionary can also be seen to be linked with more intimate, family affairs, and was used as a balm to soothe certain previous family wounds. These were mostly connected with the selling of family property back in 1903 due to the debt created by Sr. Con-

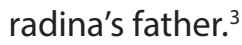
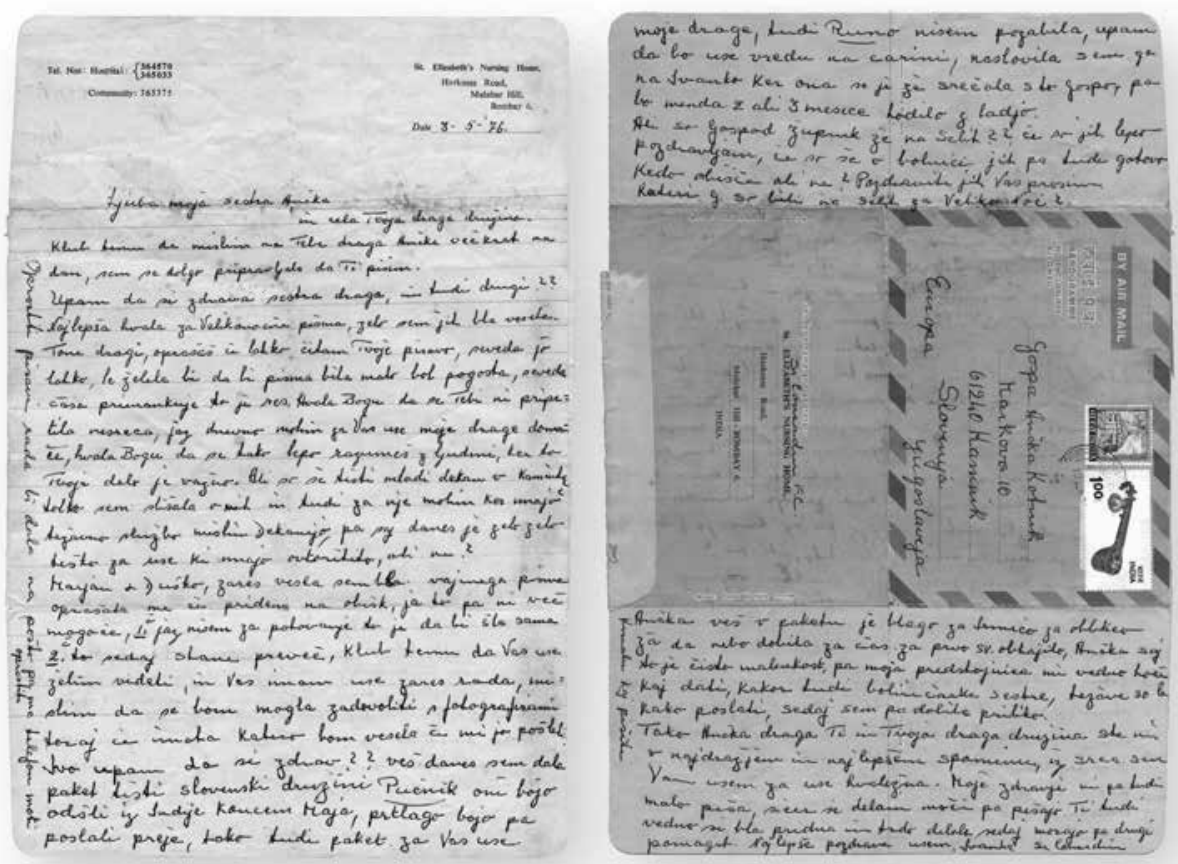

Figure 2: A letter (source: Resnik family archive).

There are several additional peculiarities regarding the material conditions of Sr. Conradina's letters. Up till 1979, the letters were mostly written on the institution's official stationery. Was she obliged to use the official stationery? Does this suggest that the pre-1979 letters were subjected to stricter control? Apart from the letters, the folder also contains one photo, one Christmas image and six postcards, mostly

From the author's ethnographic documentation. 
from around Christmas time. The postage stamps constitute another material detail. Apart from the images that they bear (airplanes, animals, workers, important men, moon with a man's face etc.), the stamps are also important objects. In several letters, the postage-stamps were removed and the handwriting is blurred due to the water used to remove the stamp. Were they removed for someone's stamp collection? The light blue envelopes with white, blue and red lines at the edges should also be taken into consideration. The grandnephew mentioned them several times in our conversation, as a specific object from his childhood. These special envelopes and postage stamps, different from the ones that circulated in Europe or Slovenia, found their way to the family post-box in the small village of Markovo, outside of Kamnik, and might have triggered curiosity or raised new questions about faraway places and the people who inhabited them. For anthropologists they also raised questions about the family who received and stored them.

\section{The Question of Comprehension: Numbers and Gaps}

Numbers and gaps have to be taken into consideration before moving to the content. One way to approach the immense quantity of data is to create a list of facts in columns along the following lines: 1 . Chronological perspective; 2 . Persons involved (identification and quantification); 3. Gaps and silences. This structured picture allows for different connections and relations and raises new questions that might be asked in future ethnographic studies.

Chronologically it was important to see that this specific collection of letters started with a time gap. The first letter from 1933 came from Zagreb and was written by sister Maria Benedicta, who informed the Resnik family about Sr. Conradina's departure. The next letter in the folder came 14 years later and was written by Sr. Conradina to her mother in 1947, followed by another gap of 13 years. But from 1960 on, more letters were written, or at least more letters survived in the family archives and these became even more regular before and after her visits to Slovenia and around Christmas time. Most of the letters in the folder were sent in the early 1970s, peaking in 1973 (12 letters). It should be noted that this chronological framework corresponds to the changes implemented by the Second Vatican Council (SVC), which also included a loosening of the prescribed roles for missionaries and missions (see Avsenik Nabergoj in this volume). Furthermore, letters were written in relation to specific events in both the home country and India (e.g. the 1963 earthquake in Skopje; the 1971 visit of Yugoslav President Tito to Delhi) or in relation to important family events (e.g. the death of Sr. Conradina's mother and her brother in-law; her nephew's graduation). Several kinds of time can therefore be said to have affected this correspondence: societal time (related to secular as well as religious political developments and specific events), environmental time (earthquakes, droughts, floods, seasons) and family time (illness, harvests, death, graduations). 
Figure 3: Facts in columns

\begin{tabular}{|c|c|c|c|c|c|c|}
\hline $\begin{array}{l}\text { LETTER nU. \& } \\
\text { nu. of } L \text {, per } Y\end{array}$ & $\begin{array}{l}\text { DATE/ } \\
\text { PLACE } \\
\text { (send from) }\end{array}$ & \begin{tabular}{|l|} 
SENDER + \\
letter details
\end{tabular} & RECEIVER & FIRST LNE & CONTENT & \begin{tabular}{|l|} 
OTHER \\
MENTIONED \\
PERSONS \\
\end{tabular} \\
\hline $\begin{array}{l}1 . \\
1933 \text { (1) }\end{array}$ & $\begin{array}{l}14 / 11 \\
1933, \\
\text { Liege }\end{array}$ & $\begin{array}{l}\text { 5. Maria } \\
\text { Bepedikta } \\
\text { Banek } \\
\text { (sister } \\
\text { from } \\
\text { Zagreb) } \\
\end{array}$ & $\begin{array}{l}\text { Exančiška } \\
\text { Besnik } \\
\text { (mother) }\end{array}$ & $\begin{array}{l}\text { Dearest } \\
\text { Mad. }\end{array}$ & $\begin{array}{l}\text { Encouraging } \\
\text { words } \\
\text { regarding C. } \\
\text { departure to } \\
\text { India. Detoils } \\
\text { on deporture. }\end{array}$ & \\
\hline $\begin{array}{l}2 . \\
1947(1)\end{array}$ & $\begin{array}{l}28 / 12 \\
1947, \\
\text { 5t. J. } \\
\text { Home, } \\
\text { Bexpold's, } \\
\text { Road } \\
\text { Beculla, } \\
\text { Bombay } \\
\text { T: } 41791 \\
\end{array}$ & $\begin{array}{l}\text { 5. Con. } \\
\text { (written on } \\
\text { orig. paper } \\
\text { 5t. Jaspeh } \\
\text { Home) }\end{array}$ & $\begin{array}{l}\text { Exančiška } \\
\text { Besnik } \\
\text { (mother) }\end{array}$ & $\begin{array}{l}\text { My very } \\
\text { deor } \\
\text { mother! }\end{array}$ & $\begin{array}{l}\text { Asking about } \\
\text { illness of her } \\
\text { mother. She } \\
\text { feels guilty not } \\
\text { being with her. }\end{array}$ & $\begin{array}{l}\text { sister } \\
\text { Bezkg. }\end{array}$ \\
\hline $\begin{array}{l}\text { 3. } \\
1960(1)\end{array}$ & $\begin{array}{l}14 / 2 \\
1960 \\
\text { Bombay }\end{array}$ & 5. con. & $\begin{array}{l}\text { Ana } \\
\text { Ketnik } \\
\text { (sister) } \\
\text { address: } \\
\text { Ivan \&/or } \\
\text { Ana } \\
\text { Ketnik } \\
\text { MarkqxQ } \\
\text { 10, } \\
\text { Kamoik, } \\
\text { SL., SFRJ }\end{array}$ & $\begin{array}{l}\text { My } \\
\text { deorest } \\
\text { sister } \\
\text { Aočkg! }\end{array}$ & $\begin{array}{l}\text { Asking about } \\
\text { nephews, } \\
\text { worries about } \\
\text { them, counts } \\
\text { year in India, } \\
\text { wishes more } \\
\text { letters from } \\
\text { fomily, } \\
\text { mentions her } \\
\text { visit home. }\end{array}$ & $\begin{array}{l}\text { nephew } \\
\text { veoka, } \\
\text { Cordinal } \\
\text { stegiaes } \\
\text { porish } \\
\text { priest }\end{array}$ \\
\hline $\begin{array}{l}\text { 4. } \\
1961(1)\end{array}$ & $\begin{array}{l}12 / 11 \\
1961, \\
\text { Bombay }\end{array}$ & 5. Con. & $\begin{array}{l}\text { Ana } \\
\text { Ketnik } \\
\text { (sister) }\end{array}$ & $\begin{array}{l}\text { Dear } \\
\text { sister! }\end{array}$ & $\begin{array}{l}\text { Gives thanks } \\
\text { for photos and } \\
\text { letters. Wishes } \\
\text { more letters. } \\
\text { Worries about } \\
\text { nephews } \\
\text { (concrete a } \\
\text { regarding } \\
\text { nephews) }\end{array}$ & $\begin{array}{l}\text { Nephews: } \\
\text { jonke, } \\
\text { Jenciek } \\
\text { urociek } \\
\text { Marigh }\end{array}$ \\
\hline $\begin{array}{l}5 . \\
1962(2)\end{array}$ & $\begin{array}{l}8 / 9 \\
1962 \\
\text { Daughter } \\
\text { s of the } \\
\text { Cross St. } \\
\text { Jos. Con. } \\
\text { Bandra- } \\
\text { Bombay } \\
\text { 50 } \\
\end{array}$ & 5. Con. & $\begin{array}{l}\text { Nephew } \\
\text { Anton }\end{array}$ & $\begin{array}{l}\text { Deor } \\
\text { Tençek! }\end{array}$ & $\begin{array}{l}\text { Congrats for } \\
\text { school finish, } \\
\text { advises about } \\
\text { job, preaches } \\
\text { on happiness. } \\
\text { Mentions/feast } \\
\text { in Bepdre. }\end{array}$ & \\
\hline 6. & $\begin{array}{l}\text { 2/9 1962, } \\
\text { Bombay }\end{array}$ & 5. con & $\begin{array}{l}\text { Ana } \\
\text { Ketoik } \\
\text { (sister }\end{array}$ & $\begin{array}{l}\text { My dear } \\
\text { sister! }\end{array}$ & $\begin{array}{l}\text { Counts } y \text {. in } \\
\text { India, advises } \\
\text { patience with } \\
\text { Mimi, asks } \\
\text { about Ivo } \\
\text { school, } \\
\text { advises } \\
\text { contocts with } \\
\text { priest and } \\
\text { more prayers. }\end{array}$ & $\begin{array}{l}\text { nephews } \\
\text { Marigy } \\
\text { Mimi, wo, } \\
\text { stonke+ } \\
\text { his fomily, } \\
\text { porish } \\
\text { priest }\end{array}$ \\
\hline
\end{tabular}

Regarding the persons involved, we can distinguish between addressees and those mentioned in letters. In our case most of the letters (46 of the total of 126) were addressed to Sr. Conradina's sister Ana. 27 letters were addressed to her nephew Tone and his family members. Her nephew Ivo received 24 letters, 17 letters were addressed to the family as a whole, and other members received 1 to 4 letters. Also interesting is the frequency of writing to certain family members. Tone received most of her letters in the period when he lived in the family house in Markovo. 
Afterwards, in the period between 1976 and 1988, it was her nephew Ivo who received most of her letters. These were letters addressed to her family house. Apart from the family members there were numerous other people who were mentioned in her letters. Some of these were: the local parish priests, a theologian from Ljubljana, Ursuline sisters, Bosnian workers (whom she calls "southern brothers"), neighbours and family friends from Slovenia. We also hear about her patients in India, other missionaries, Yugoslav politicians visiting India (there's a mention of Tito), migrants from Bangladesh, a student from Maribor (whom she calls a communist), and so on. All these different people that found their way into her letters speak of the connections that were established between places, people and ideas. They testify to the fact that migrants' letters were a source of wisdom about life in new locations and a means of connection across various boundaries.

The other day we went for a picnic and spent the whole day by the sea. It was nice, there was singing and joking for the entire journey. There were 4 sisters, 26 patients and 3 cooks. Everything here in India would be so much better if they hadn't the wretched caste problem, with everyone going by their caste, and especially amongst the workers this is a big obstacle. And so the cook won't clean the dishes, let alone scrub the kitchen. (19 March 1972)

Sr. Conradina emerges as a person with broad communication skills, not only regarding her linguistic abilities (she spoke English, French and Croatian, and maybe also some Hindi and Marathi) but also regarding her communication with people from different cultural and social milieus. Although her sister would not have had the chance to talk with the Yugoslav ambassador in India, or with Conradina's Indian patients and their families, she was able to indirectly get to know all of them.

The gaps and silences call for further reflection; sometimes they simply speak for themselves. Is it possible that Sr. Conradina's first letter to her family was sent 14 years after her departure? Wouldn't she also have written home from Zagreb, where she worked as a medical assistant and where she first heard about missionary work in India? Were the letters from India deemed more precious and therefore worthy of keeping? What about her first 10 years in India? Is the absence of these letters simply the consequence of the restrictions that demanded strict separation between the missionary and her family? We can also never be sure how many letters were destroyed for various reasons, i.e. inadvertently or simply because they may have contained embarrassing content. Sr. Conradina's experiences in Zagreb and her first years in India, the experiences that could reveal her aspirations and expectations regarding missionary life, remain a mystery. Another rather unexpected silence in her letters is a lack of information regarding India. Does it simply reveal her lack of interest in the local culture or did she assume that this kind of information would be uninteresting to her relatives, as her grandnephew has suggested? 
Figure 4: Sr. Conradina's family tree

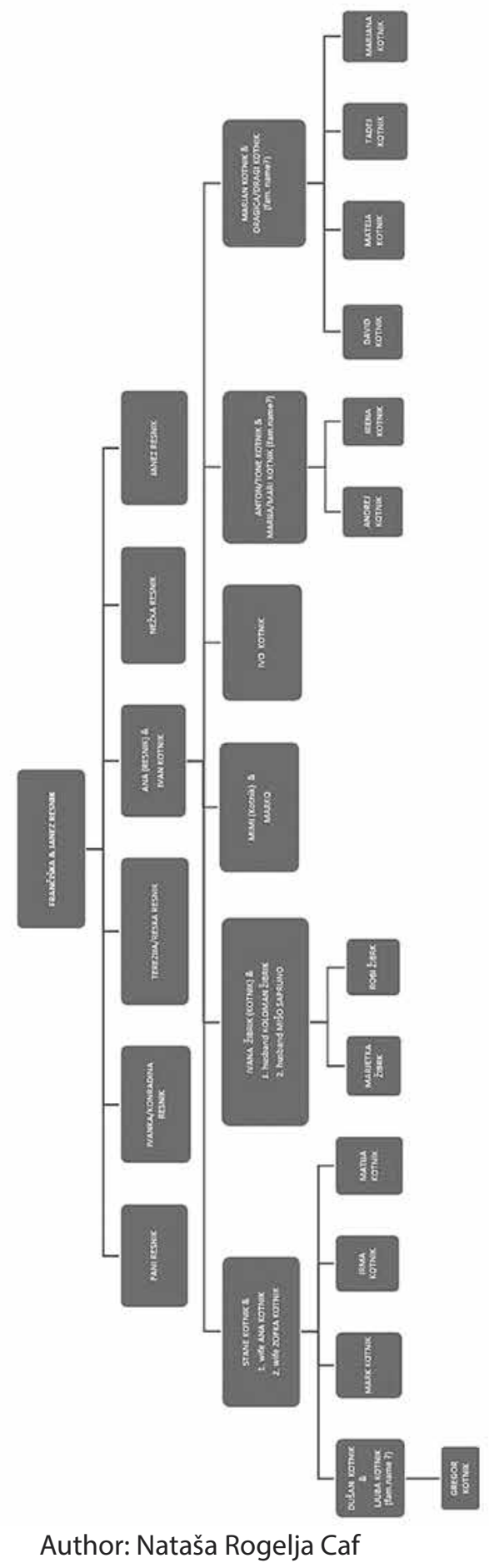


Finally, it is also important to acknowledge repetitive patterns. Repetition might serve as an entry point for content analysis or/and further ethnographic research. Although we did not use electronic coding approaches that might also be useful for letter analysis (such as ATLAS.ti and NVivo), certain themes appear, as odd as the frequent mentioning of home-grown pears and other fruits (mostly apples). In more than half the letters, Sr. Conradina implored her relatives to correspond with her using the exact same phrase: "Why don't you write to me more often?" Her constant longing for home found expression in different, often repeated, formulations: missing home, missing the family, loneliness, longing for the home country, homesickness, the joy of speaking and reading in Slovene.

\section{Declaration of Contents: People, Events and the Plot}

We can now move to the next level, namely to the declaration of contents, including the characters, events, topics and the whole "plot of the story". In addition to the classical content analysis of data, genealogy research also proved useful for our purposes. Especially for understanding "characters", genealogy research, interlinked with ethnography, offers great potential for researchers seeking to understand the cultural and historical circumstances in which letters were written. A simple sketch of the family tree can be a solid entry point for clarifying the connections between the characters and the events mentioned in the letters. Sr. Conradina's family tree covers four generations and was created in two steps. First I created a simple graphic image with names. I then added different data and stories connected with specific people, linking the family tree with the stories gathered through ethnography and content analysis of the letters. Finally, I sketched some conclusions that were further tested within the research group. The three main clusters around which the letters are condensed can be described as: family, home country and (care) work.

The letter archive in question is primarily a family correspondence, and not so much a person-to-person correspondence, even though most of the letters were specifically addressed to one person. Often there were several letters inside one envelope. Apart from the economic aspect, this practice also underlines the notion of family correspondence; the letters were most probably written for everyone to read or to be shared. The most accentuated topic in her letters was the attachment to her home country and family. Often this gave rise to the expression of a tension between a longing for family on the one hand and a fondness for her profession on the other. Notwithstanding her attachment to her family, which lasted throughout her life, Sr. Conradina was very much devoted to her role as a nurse, especially after she started working at St. Elisabeth's Hospital in Bombay.

I wish my family was closer. I do not regret my decision but still I love my family so much... (21 February 1963) [...] By nature people are weak. My weakness is my 
constant longing for family back home (27 July 1965). I have a lot of work but it is not too hard and I am really doing well. I get along very well with the other sisters, the nurses and doctors and of course with the patients. I help them to the best of my abilities and almost all my patients say they feel like they are at "home" and not in the hospital. Every day I speak with them, I ask them how they feel, if they like the food ... (25 April 1967)

Sr. Conradina constantly prays for her family, she thinks about her relatives in times of harvest, difficult situations (sickness, death, etc.), graduations and other important events. In other words, she remained deeply involved in family affairs, even though she lived thousands of miles away. She writes: "Mimi, did they start building the street? Does it pass by your house?" (31 December 1968) [... "Is Stane's room already finished? Where is it located? You know, I want to know everything, I remember all of you in my prayers every single day, especially you (sister Ana) and Stane (the oldest nephew)" (1963). "Are the apples already ripe?" (17 September 1974). Time is another important topic in her writings. In several letters she counts years spent away from her home, she often uses the phrase "how time flies", and several times she brings up the idea of eternal time, the time when she will be re-joined with her family. "It's been 38 years in India and 41 since I left home. Home and family are always first, after God (5 December 1971) [...] ... when we come to eternity, there will be no separation any longer and no tears" (3 March 1972).

In the letters we can also sense her constant struggling to remain part of the family, despite her having left it, and to maintain her position in it. She often gives advice to her nephews and nieces as well as to her sister. Most of the time, her advice is not a general sermon on life, though she can also be preachy, but more often than not it is mother-like concern directed at very concrete issues related to her nephews and nieces. Often she worries that she might be bombarding her family with letters and frequently she longs for their answers. "What happened? Why don't you write to me? I find it very hard if you don't write!" (22 May 1965).

Moving from family to broader issues of home country and language, one notices that food, books, trees and encounters with other Slovene or Yugoslav people hold a special place in her letters. Food is mentioned in relation to holidays, but specific items are also referred to, including, most frequently, dried pears and apples. Again this can be linked with her family history, as the pear tree near the family house was her mother's favourite tree. ${ }^{4}$ She also longs for pine trees, especially around Christmas time, and several times she mentioned willow trees that she brought from Slovenia and planted in India.

We can also learn from her writings that she regularly received Slovene books and journals (e.g. the Slovenian Catholic weekly Družina [Family] from Slovene priests and colleagues from Ljubljana. She often described encounters with Slovenes or

4 From the author's ethnographic documentation. 
other Yugoslavs abroad (Croatian sisters, Slovene students, Yugoslav ministers and consuls, Slovene immigrant societies and occasional guests) and she always wrote how good it was to speak in her own language (this also included Croatian, from where she was standing). Several times she tried to connect Slovenes abroad with her family back home (e.g. by suggesting letter exchanges with her nephews).

Even though family and home country are the focus of her writings, she does occasionally write about events in India, putting English or Indian words in her letters, and encouraging her nephews to learn foreign languages. On one occasion she explains about Buddhism and Hinduism and, especially from 1970 on, she sometimes describes people and broader societal problems in India. She often comments on politicians visiting India, especially Yugoslav ones, and though she is critical towards communism, she writes very positively about President Tito, stressing several times that he is someone striving for peace. Once she informed her family of she and a Croatian sister had sent a Christmas card to Tito. "You know Mimi, a Croatian sister and I wrote a Christmas card to Tito. I will tell you if we get a reply" (31 December 1968).

The "plot of her story" follows the development of the family events in Slovenia. Through her letters we learn more about her family and Slovenia than we do about India, although from the 1970s on we get more information about India, mostly regarding her professional work in the hospital as well as descriptions of encounters with other people in India. Still, these are bits and pieces, scattered across the story of her family. A short walk through her thoughts nicely outlines the plot of her story:

19 February 1960: Beloved mother, hearing about your illness I find it very hard not to be by your side. But this is impossible now ...

2 September 1962: How time flies! I can hardly believe it; it's been 32 years since I left home...

1 June 1964: Did Ivanka find an apartment?

22 May 1965: What happened? Nobody writes to me!

8 June 1966: I hope your dad's arm is getting better ...

12 August 1971: I was thinking about you, how you dried and baled the hay, and I miss you all ...

10 March 1979: Just yesterday, I learned that Kardelj died. I hope Tito is healthy. God help him!...

2 December 1979: You know Ančka, home and family as well as your homeland you can never forget ...

27 February 1983: When the primroses bloom, send me one in a letter from the home garden. Do you still have any snowdrops? I used to plant them a lot [...] Here in the hospital there is a lady. She is very weak and I feed her every day ...

13 March 1984: Dear Ivo! I would like to express my sincere sympathy on the occasion of your father's death ... 
17 August 1986: I asked Ivo for willow branches, I planted them and they are growing ...

15 March 1987: Is it true that the Serbo-Croatian language will take over, I hope not [...] God save Slovenia ...

8 December 1988: (Ivo) take a bold step, find a woman and marry her ...

24 May 1989: You know Irena, a few days ago I saw a huge elephant kneeled down so people could descend ...

2 July 1993: I wrote you a long letter but maybe you will not be able to read it. I have poor eyesight and my hand is shaking ...

\section{Connecting Small Places with Large Issues: ${ }^{5}$ Longing for Family, the "C'mon Ana!" Anecdote and ... Lots of Elephants}

The combination of ethnography, family letters and memories all testify to what Shannon Perry (2012) has noted regarding personal or family stories and how they always complicate cultural stereotypes. They encourage the re-examination of taken-for-granted "truths" and they bring one face to face with stories and experiences that simultaneously do and do not belong to us. The "C'mon Ana!" anecdote tell us about Sr. Conradina herself, and it also speaks about her sister Ana's expectations regarding missionaries and their way of life. Finally, it also speaks of us, who most probably find this anecdote amusing. We are asked to confront our own stereotypes regarding women missionaries and nuns, which can easily overshadow some important questions. The moment of reflection that includes the reader and the present context is exactly the contribution that anthropology can make in the analysis of letters.

"What was she like, honestly?" we found ourselves asking her grandnephew after reading and analysing the letters? "She was fond of life and cheerful," he replies instantly, "in fact, she was an oddball, different to any of us." That is how he remembers her, that was her image in the family even before she left for India. He adds a story that triggered his memory in relation to our question. "Together with my granduncle Janez - from another family, so to say, and an outcast, who could not find himself in Markovo and sadly ended up as an alcoholic in the hospital for incurables in Mengeš - they once escaped to the local dance. It was a time of fasting and our family was very religious. But they still did it."

A lot can be said about agency on the basis of Sr. Conradina's material. I don't want to suggest that (Slovene) women missionaries were by definition "outcasts" or "activists" but, as stressed by Jelnikar (in this volume) it seems important to think

5 Borrowing the expression from anthropologist Thomas Hyland Eriksen (2001).

6 From the author's ethnographic documentation.

7 See footnote 6. 
about these women as active agents on the trajectory of change in the societies where they worked as missionaries as well as in their home societies, rather than as merely passive recipients of 'God's will' as dictated to them by their superiors. It is hardly surprising that the woman who embarked on a long journey to India one Tuesday night on 9 November 1933 is also the woman who escaped to the local dance and is remembered as jovial.

There is a notable tension between her religious and patriotic sentiments in her correspondence, leading towards the conclusion that missionary work, as Sr. Conradina lived it, was a specific personal juggling between a religious calling, patriotic sentiments and her personal aspirations. It is important to note that she came from a rural, religious environment of what later became communist Yugoslavia. On several occasions she wrote how she hated to travel, how difficult it was for her to travel alone, but also that she refused to join the Croatian sisters who in 1971 invited her to join them in Zagreb. She refused this offer despite the fact that this might have brought her closer to her family again. It was important for her to stay on in India. Could it then be that her missionary work provided an active resolution of a personal position in a specific local environment, where women were expected to be married and faith was in constant tension with state ideologies?

Finally, we have to give some space to the idea of the missionary as an agent of change in their home environment. Despite the fact that there are few words about India and other countries in her letters, Sr. Conradina did establish new connections, for example, through her English friend Peace who came to visit Markovo, by meeting Slovene and Croatian immigrants and other people whom she introduced to her family in letters or in person. Furthermore, she answered her nephews' questions about Buddhism, she encouraged them to learn new languages, she spoke about floods and migrations in India, she introduced them to her patients and their families. Finally, she also advised her family on various issues from her own unique position and was at the same time well aware of the stereotypes people held. She wrote once: "Ivan, you might say she knows nothing because of all these years she lived behind the cloister walls. But believe me, I have a lot of experience, working all these years with very different people, people with different problems" (29 July 1965).

Although one might draw the conclusion from her letters that she did not evince any great curiosity for the foreign country in which she lived for many decades (from 1933 till 1997), her input to the home environment was obvious. We once visited her niece Ivanka, a kind lady in her late seventies, the only relative to have once visited her in India. We felt like we should have come and talked to her a decade ago, when her memory would have been much more vivid. But looking around her house there were numerous colourful blankets and sculptures of elephants staring at us without any special explanations while we were having our conversation. They were like silent witnesses of the fact that Sr. Conradina, as well as the wooden Indian elephants, were an important part of this family. 
After she passed away on 24 May 1997, the family received one final letter from India, written by Sr. Zita from St. Elisabeth's Hospital in Mumbai. Let us finish with her thoughts:

Her great love for her country and her language was evident in the keen interest she took in all the literature she received from Yugoslavia. In her not so lucid moments she often spoke in her language and it was a great pity that none of us were able to understand. Once in a while sister received visits from friends from Yugoslavia. Brother Ludwig, a Salesian brother, now living in Goa, was one of them. Sr. Conradina's face radiated with rare joy when she chatted away with brother in her own language. (25 May 1997)

\section{REFERENCES}

Bofulin, Martina (2018). O mlečni formuli in plenicah: Prepletene mobilnosti predmetov in ljudi v kitajskih transnacionalnih družbenih prostorih. Dve domovini / Two Homelands 47, 147-162.

Denzin, Norman (1960) (ed). Sociological Methods: A Sourcebook. Chicago, London: Aldine.

Elliott, Bruce S., Gerber, David A., Sinke, Suzanne M. (2006). Introduction. Letters Across Borders: The Epistolary Practices of International Migrants (eds. Bruce S. Elliott, David A. Gerber, Suzanne M. Sinke). New York, Hampshire: Palgrave Macmillan, 1-25.

Eriksen, Thomas Hylland (2001). Small Places, Large Issues: An Introduction to Social and Cultural Anthropology. London, Sterling Virginia: Pluto Press.

Frisch, Michael (2006). Oral History and the Digital Revolution: Towards a Post-documentary Sensibility. The Oral History Reader (eds. Robert Peaks, Alistair Thomson). London: Routledge, 102-114.

Gerber, David A. (2006). Epistolary Masquerades: Acts of Deceiving and Withholding in Immigrant Letters. Letters across Borders: The Epistolary Practices of International Migrants (eds. Bruce S. Elliott, David A. Gerber, Suzanne M. Sinke). New York, Hampshire: Palgrave Macmillan, 141-157.

Hall, David (2015). Worktown: The Astonishing Story of the Birth of Mass-Observation. London: Weidenfeld \& Nicolson.

Hovland, Ingie (2009). Follow the Missionary: Connected and Disconnected Flows of Meaning in the Norwegian Mission Society. Multi-sited Ethnography: Theory, Praxis, and Locality in Contemporary Social Research (ed. Mark-Anthony Falzon). Farnham: Ashgate, 135-147.

Jolly, Margaretta (2012). Memory, Narrative and History: Critical Debate, New Trajectories. Working papers on Memory, Narrative and Histories (ed. Graham Dawson). Brighton: Centre for Research in Memory, Narratives and Histories, 47. 
Kalc, Aleksej (2004). Pisma in magnetofonski trakovi kot komunikacijska sredstva in viri za preučevanje izseljenstva: Primer tržaške družine v Avstraliji. Dve domovini /Two Homelands 20, 153-174.

Karlekar, Malavika (1993). Voices from Within: Early Personal Narratives of Bengali Women. Delhi: Oxford University Press.

Kokalj, Jože (1989). Pogovori ob Gangesu. Knjižnica misijonskih obzorij 3. Ljubljana: Župnijski urad Dravlje.

Lambert Hurley, Siobhan (2013). Life/History/Archive: Identifying Autobiographical Writing by Muslim Women in South Asia. Journal of Women's History 25/2, 61-84. Madianou, Mirca, Miller, Daniel (2012). Migration and New Media: Transnational Families and Polymedia. London: Routledge.

Milharčič Hladnik, Mirjam (2009). Moje misli so bile pri vas doma: Poti prehodov v pismih. Krila migracij: Po meri življenjskih zgodb (ur. Mirjam Milharčič Hladnik, Jernej Mlekuž). Založba ZRC: Ljubljana, 30-33.

Perry, Shannon (2012). The Other in Us: Anthropology, Genealogy and Kinship in the 21st Century, http://www.anthropologiesproject.org/2012/04/other-in-us-anthropology-genealogy-and.html (20. 2. 2019).

Radin, Paul (1926). Crushing Thunder: The Autobiography of an American Indian. New York: Appleton.

Rogelja, Nataša (2014). „Vse po resnici«: Uporaba biografske metode ob raziskovanju Šavrink. Dve domovini / Two Homelands 40, 35-46.

Saunders, Max (2010). Self Impression: Life-Writing, Autobiografiction, and the Forms of Modern Literature. Oxford: Oxford UP.

Smith, Sidonie, Watson, Julie (2001). Reading Autobiography: A Guide for Interpreting Life Narratives. Minneapolis: University of Minnesota.

Smith, Sidonie, Watson, Julie (2009). Subject Formations beyond the Book: Visual-Verbal-Virtual Contexts of Life Narrative. Keynote Lecture at the Work of Life-Writing International Conference, King's College London, May 26, 2009.

Stowe, Steven (2002). Making Sense of Letters and Diaries. History Matters: The U.S. Survey Course, http://historymatters.gmu.edu/mse/letters/ (22. 2. 2019).

Thompson, Paul (1988). The Voice of the Past: Oral History. Oxford, New York: Oxford University Press.

Thomson, Alistair (2007). Four Paradigm Transformations in Oral History. Oral History Review 34/1, 49-70. 


\section{POVZETEK}

\section{ŽIVLJENJE V PISMIH: ANTROPOLOŠKA REFLEKSIJA KORESPONDENCE SLOVENSKE MISIJONARKE, SESTRE KONRADINE RESNIK Nataša ROGELJA CAF}

Članek predstavi družinski arhiv pisem, ki jih je slovenska misijonarka, sestra Konradina Resnik, v prvi polovici prejšnjega stoletja pošiljala svoji družini v Slovenijo. Prvi del članka je namenjen orisu nekaterih zgodovinskih okoliščin, pomembnih za razumevaje kvalitativnih metodoloških pristopov, kamor se umešča tudi analiza pisem. Osrednji del članka na primeru pisemskega arhiva družine Resnik ponuja vpogled v različne, za analizo pisem pomembne plasti (materialni aspekt, vprašanje obsega, vsebinska analiza, etnografski kontekst itd.). Pisma so namreč med pomembnejšimi dokumenti za preučevanje dediščine ženskega misijonarskega dela, članek pa se $\mathrm{s}$ tem pridružuje redkim naporom konkretnih opisov metodoloških pristopov, ki v analizi pisemskega gradiva upošteva tudi etnografijo. Čeprav je osrednji fokus članka metodološki, besedilo prinaša tudi veliko vsebinskih podatkov o sestri Konradini Resnik, njeni družini ter širši problematiki slovenskih misijonark v Indiji. Na temelju predstavljenih vsebinskih drobcev besedilo odpira številna za preučevanje slovenskih misijonark v Indiji pomembna vprašanja, kot npr.: kako se pri slovenskih misijonarkah odražajo širši političnozgodovinski konteksti, v katerih so se znašle (ali iz katerih so izšle), kako so se umeščale v različne hierarhije in razmerja moči in kako so $v$ danih situacijah delovale same oz. kako so vplivale nanje. V zaključku se članek vrne na svoje izhodišče in osvetli akterko samo, slovensko misijonarko v Indiji, ki je v okviru različnih hierarhij, diskurzov in odnosov svojim domačim pošiljala pisma. 